\title{
Ingrid Wehr*
}

\section{On the Problematic Coexistence of Democracy and Blatant Social Inequality in Latin America}

\section{The Obstinate Persistence of Structural Social Inequality in Latin America}

At the beginning of the 21st century - with the exception of SubSaharan Africa - Latin America has the highest levels of inequality worldwide. These disparities do not only find their expression in extreme inequalities in income and assets, but also in a series of asymmetries concerning the distribution of and the access to a considerable number of material and public goods such as land, education, social security, and health. ${ }^{1}$ A look at the differences in income serves to illustrate these shocking disparities in a graphic manner: In the year 2005, a person belonging to the top decile of households, on average, earned 17 times more than a person belonging to the poorest $40 \%$ of households (CEPAL 2010: 185). In countries like Brazil, marked by higher-than-average income inequalities, the lowest decile's share of the national income equaled a meager $0.9 \%$ while the share of income earned by the richest decile was $43.5 \%$ (Barros et al. 2010: 134). What is interesting about the inequality levels in Latin America is the fact that sharp differences concerning the respective levels of development (measured by BIP/per capita) notwithstanding, all Central and South American countries without exception are characterized by above

* This is an adapted version of an article which originally appeared as "Wohlfahrtsregime und soziale Ungleichheit in Lateinamerika" in: Wehr, Ingrid/Burchardt, Hans-Jürgen (2011) (eds.): Soziale Ungleichheiten in Lateinamerika. Baden-Baden, pp. 257-281. I am grateful to the Nomos publishing house for having granted permission to publish an English version of it. I am also indebted to Hans-Jürgen Burchardt, Tanja Ernst, Rosa Lehmann, Reinhart Kößler and Beate Rosenzweig for constructive comments on earlier versions of this article. Jörg Baten contributed valuable information on the results of latest research by economic historians.

1 For an overview of the latest research on social inequality in the region see: CEPAL (2010); Deininger/Squire (1996); ECLAC (2009); Lopez/Perry (2008); Machinea/Hopenhayn (2005); Milanovič/Muñoz de Bustillo (2008). 
average inequality rates. Even those states showing relatively low levels of income inequality (i.e., Uruguay and Costa Rica) still exceed those of relatively inegalitarian industrial or newly industrialized countries in other regions (Segura-Ubiergo 2007: 263).

Apart from blatant income inequalities, Latin America is also notorious for its extreme concentration of land holdings. The Gini coefficient measuring the disparities of land distribution reveals national and regional standards well beyond those of other regions of the world (Deininger/Olinto 1999; Ferranti et al. 2004: 436; Frankema 2009: chap. 3). ${ }^{2}$ A case that may illustrate these extreme inequalities is that of Bolivia. Despite the agrarian reform of $1953,86 \%$ of Bolivian peasants in the 1980 s manage only $2.4 \%$ of the arable land while the lion's share has remained in the hands of a tiny minority $(0.22 \%$ of the population) of large landowners (Weisbrot/Sandoval 2008: 2-3). Such gross disparities of landholdings are the rule, rather than the exception in the region. In Frankema's (2009: 52) top twenty list of states that show the highest Gini coefficients concerning land distribution, there are no less than 16 Latin American countries. Remarkably, on a worldwide scale, Latin America is the only region ${ }^{3}$ showing very little intraregional differences relating to land concentration. ${ }^{4}$ Though claimed regularly by different social movements in the course of the 20th century, most noticeably in the context of the Mexican revolution, comprehensive land reforms contributing to a significant deconcentration of ownership patterns largely failed. Unlike East Asia, the reform processes of the 1950 s to 1970 s, which put an end to the traditional hacienda economy, left the extreme disparities in land ownership largely intact (Frankema 2009: 206; Kaltmeier 2011; UNRISD 2010: 63-65).

2 Ewout Frankema's analysis is based on a comprehensive data set of 110 countries worldwide. For a short overview see Frankema (2009, table A.3.1: 213217).

3 In this context "region" is not defined geographically but refers to a group of countries which, due to their specific (post)colonial experiences, dispose of comparable trajectories of socio-economic development and authority structures. About "region" as an analytical category see Bunce (2000: 722); Mainwaring/ Pérez-Liñán (2007).

4 This finding contradicts Easterly's (2007: 756s.) hypothesis that explains the concentration of land ownership with geographical and climatic factors, i.e., the prerequisites for cash-crop production. 
Similar disparities characterize the availability of public services such as health and education (Peters 2011; Tittor 2011). At the beginning of the 21 st century the vast majority of the Latin American population, among them women without work contracts within the formal economy, agricultural workers, indigenas and afro-decendentes still lacked access to adequate medical care and high quality education. Though public education and health care systems exist in practically all Latin American countries, they are notorious for their low quality and inability to sufficiently cover all ages, especially in rural areas. Compared to other regions of the global South illiteracy rates are rather low and school enrolment rates high. What differentiates Latin America's public education systems from those in other regions is their extremely low quality and high segmentation (Frankema 2009: chap. 4; Peters 2011). According to the World Bank Report "Poverty Reduction and Growth: Virtuous and Vicious Circles" (World Bank 2006: chap. 9) school careers are still mainly influenced by the parents' level of income and education. Low levels of education are closely linked to poor chances on the labor market.

As a consequence, a vast majority of Latin American citizens remain excluded within rather than from society (Kronauer 2006; Neves 2007: 206-210; Souza 2008). The aforementioned disparities concerning the distribution of income, assets, and the asymmetrical access to essential public goods constitute protracted, structural forms of social inequality transmitted from generation to generation. They are characterized by lasting constraints on the "opportunities of access to commonly disposable or desirable social goods and/or social positions" and thus "the life chances of affected individuals, groups or societies" (Kreckel 2004: 16).

An extensive and long-lasting debate across disciplines has been concerned with the origins and exact timing of these blatant social inequality rates in Latin America. Some area specialists argue that the extreme inequality levels form a continuum throughout Latin American history since the Conquista or a fatal "Latin American equilibrium" (Acemoglu/Robinson 2006; Engerman/Sokoloff 2005; 2006; Robinson 2008; 2010). Contrary to these claims of continuity, the latest research by economic historians has revealed that serious levels 
of social inequality are a relatively recent phenomenon. ${ }^{5}$ According to the preliminary findings of these analyses, which still lack a sufficient database, national income disparities in Latin America in earlier centuries did not differ significantly from those of European states in the 19th century before the Industrial Revolution (Williamson 2010). ${ }^{6}$ Despite some difficulties concerning reliable data, what can be taken as certain is the fact that the blatant regional inequality rates are mainly a product of the processes of state-building and economic modernization after the wars of independence. A number of recent studies show that income inequality throughout the region rose rapidly at the end of the 19th century and then remained above the international average until today, although revealing a wave-shaped pattern of secular inequality trends (Frankema 2009: 205-210).

Considering the fact that Latin America is characterized by a long - albeit variable - democratic history and relatively well-entrenched welfare regimes, the consistency of extreme inequality rates poses some important questions. Despite the growing democratic thrust, the significantly enhanced participation chances, so far, have not translated into improved social inclusion or the dismantling of structural social inequality. The unresolved tension between democratic processes of decision-making and ingrained social inequalities thus constitutes a permanent political problem with a high potential for conflicts and tensions. Additionally, it raises a number of questions that challenge comparative research on democratization and social inequalities.

\section{The Unresolved Tension Between Democracy and Inequality as a Theoretical Challenge}

The obstinate persistence of extreme and ingrained social inequality in the region resists conventional explanations put forward by moderni-

5 See Baten/Mumme (2010); Bértola et al. (2009); Coatsworth (2005; 2008); Dobado Gonzáles/García Montero (2010); Frankema (2009); Milanovič/Lindert/ Williamson (2008); Prados de la Escosura (2007).

6 In order to establish levels of inequality economic historians use a number of instruments: Apart from so-called social tables, documenting income disparities between different occupational groups, the analyses are based on information about differences concerning the educational level and heights of different population groups. 
zation theorists. These theories proceed from the assumption that within the wider context of economic and social modernization processes social inequality is a necessary by-product of a transitory nature. According to the Kuznets hypothesis (Kuznets 1955), ${ }^{7}$ quite popular during the Cold War era, alongside growing technological development the demand for qualified workers increases and - at the same time - demand for unqualified workers shrinks. This leads to elevated levels of income inequality during phases of economic innovation. As national states react with higher investments in human capital, the initial rise in income disparities can be attenuated in the transcourse of the innovation and industrialization process. Contrary to these projections, the blatant income disparities inside Latin American states did not change significantly despite profound modernization processes during the 20th and 21st centuries, neither do countries with higher levels of industrialization or economic development (measured by BIP per capita) show lower levels of income disparities than less developed ones (ECLAC 2009: 90). In a clear contradiction to Kuznets' assumptions, regional trends of income disparities do not show a U curve trajectory but a wave-like pattern. Despite these fluctuations, inequality levels in all countries of the region have remained above the international average since the end of the 19th century (Frankema 2009: 12, diagram 2.1).

The persistence of above-average inequality rates does not only challenge the basic assumptions of modernization theory, but also poses some problems for democratic theory. Theorists from Aristotle to James Madison and modern theorists in the field of political economy conventionally start from the assumption that democratic processes of decision making necessarily lead to a more egalitarian distribution of income, property, and the access to essential goods (Lenski 1966; for a summary see Merkel 2010: 57-58.). Different variations of the median voter theorem building on Meltzer's and Richard's model (1981) argue that political parties with a serious interest in winning the next election feel obliged to take into consideration the central interests of the median voter. The poorer the median voter

7 Kuznets identifies technological development as the central cause of changing income patterns. For recent research findings and a critical discussion of Kuznets see Escobar (1995: 80); Kahhat (2010); Korzeniewicz/Moran (2009: 3-5). 
the higher the pressure on the governing parties to redistribute income and assets through taxes and transfers.

In Latin America, however, contrary to the basic premise of all median voter models, the current democratization phase did not lead major redistributive efforts despite the extreme levels of inequality. Since the mid 1990s Latin American countries have made some successes as far as poverty reduction policies are concerned. Poverty has been reduced by $15 \%$, extreme poverty by $9.6 \%$ (CEPAL 2010: 19-20). This progress in poverty reduction, however, was not matched by a significant change in patterns of inequality. As (re-)democratization processes coincided with neoliberal structural reforms, inequality levels initially rose after the end of the authoritarian period. Starting in the late 1990s this trend gradually reversed, at least for some countries. The average regional Gini coefficient was reduced by 4\% (ECLAC 2009: 19; López-Calva/Lustig 2010). Comparing historical rates, the regional average is thus close to levels in the 1980s. On a global scale, national inequality rates nevertheless remain on an above-average level for all countries of the region without exception.

Some critics of the median voter theorem argue that the basic assumptions of the different models derived from Meltzer's and Richard's (1981) seminal article are too simplistic (Anderson/Beramendi 2008; Hettich/Winer 1999; Huber/Pribble/Stephens 2009: 177-180). These criticisms notwithstanding, the basic assumptions sustained by median voter models still point to some of the central questions of current research on democratization processes in Latin America. Why did improved democratic political participation not translate into improved social inclusion? Why did the longest democratic period in Latin American history since independence have practically no impact on inequality rates to date? Today, three decades after the beginning of the third wave (Huntington 1991) of democratization, three quarters of the Latin American population have to manage with less than the average income, that is, $40 \%$ with less than half of the average income (ECLAC 2001: 71). Findings of opinion polls clearly state that three quarters of the Latin American population are well aware of these inequalities and criticize them as unjust or extremely unjust (CEPAL 2009: 25).

A look at the results of comparative research on inequality and democracy in Europe reveals a clear link between the expansion of 
the suffrage during the 19th and 20th centuries and the reduction of income inequalities and access asymmetries, especially in as far as education opportunities are concerned (Acemoglu/Robinson 2000; 2006; Boix 2003; Huber/Stephens 2001; Lindert 2004). These findings do not hold true for Latin American electoral and democratic history. With the exception of the Caribbean, the great majority of the Latin American states became independent between 1810 and 1830 , that is, considerably earlier than most countries of the global South. The following processes of state and nation building were accompanied by an important surge in democratization. With the noticeable exception of Brazil, which remained a monarchy until 1889, all newly independent states chose republican, presidential forms of government. At the same time as - or even earlier than its European counterparts - male suffrage was expanded from the first half of the 19th century onwards. Electoral history was not smooth but instead characterized by a number of setbacks. On a global scale, however, suffrage regulations in a considerable number of Latin American countries were quite advanced, at least as far as (white) males were concerned (Annino 1995; Engerman/Sokoloff 2005; Posada-Carbó 1996; Sabato 1999; on the exclusion of women Caulfield/Chambers/Putnam 2005). What needs explanation is the fact that despite early decolonization and democratization processes, Latin American countries did not succeed in changing the overall pattern of above-average social inequality. The problematic coexistence of democratic processes of decision making and structural social inequality poses a number of tricky questions as it cannot be explained by institutional deficiencies or a lack of political participation, interest or of political culture on part of the citizens.

A closer look at the commonly used democracy indices clearly reveals Latin America's democratic edge as compared to other regions of the global South. Unlike most countries in Africa and Asia, Latin American political systems are characterized by comparatively free, fair and transparent electoral processes (PNUD 2004), and well-entrenched political participation rights. On the widely used Freedom House Index, produced on an annual basis, measuring explicitly political rights, Latin American countries score high compared to 
other regions, including parts of Eastern Europe. ${ }^{8}$ Political parties are generally allowed to operate without any major impediments, and party candidates are selected via democratic mechanisms. In the last couple of years a number of legal norms have been passed directed towards improved participation for groups formerly disadvantaged (women, indigenous groups, and Afro-Americans). ${ }^{9}$

Especially noteworthy in this context is the fact that citizen participation in politics is not confined to national, federal or local elections. Some states within the region are real laboratories for new forms of citizen participation and engagement, as shown most clearly in the vast experiences with participatory budgeting, a model now exported to Europe (Avritzer 2009). Contrary to the findings of electoral research focused on industrial states that indicate a link between active citizen participation and a higher socio-economic status, research on Latin America shows that poor and marginalized citizens do make use of their electoral rights on a regular basis (Fornos/Power/Garand 2004). Whereas in industrial states, economic crises lead to lower electoral participation (Schäfer 2010), data on Latin America indicate the opposite effect: electoral participation rises in times of crises. (Benton 2005). Consequently, the persistence of inequality and low priority assigned to social questions on the respective political agendas cannot be explained by widespread political exclusion or political apathy of marginalized citizens.

Neither can it be attributed to institutional deficits as the literature on democratic transitions suggests. Transitologists usually argue that Latin American democracies constitute a diminished subtype of the established, liberal democracies in the global North. Progress concerning electoral and political rights notwithstanding, Latin American political systems still suffer from institutional deficiencies ${ }^{10}$ in other areas of the broader political regime. Although democratic elections

8 In 2010 only Cuba was labeled as unfree. Nine (26\%) out of 35 Latin American states (including the Caribbean) were ranked as "partly free" on the basis of the index built on two scales on political and civic rights. This group comprised the following states: Bolivia, Colombia, Ecuador, Paraguay, Venezuela, Guatemala, Honduras, Nicaragua and Haiti.

9 For a summary on the political participation of women see Oettler (2011), for indigenous groups Ernst (2011).

10 For a typology of defect democracies in Latin America see Thiery/Merkel (2010). 
and political participation are central elements of democratic regimes, they are not sufficient for guaranteeing the political system's ability to take into consideration the needs and interests of the majority of the poor voters. According to this perspective, and in order to enhance responsiveness, a number of additional criteria have to be met:

Firstly, the vertical control of political representatives via regular, free, and fair elections has to be supplemented by a further, horizontal dimension of control guaranteeing the division of powers and greater overall accountability. Secondly, apart from political rights, strong civic (defence) rights are needed in order to define the limits of legitimate state power and strengthen the principles of the rule of law. And finally, democratically elected governments must have the power to decide on political issues without interference from internal (i.e., the military) or external actors (i.e., hegemonic powers like the United States) (Merkel 2010: 31-35).

Based on neo-institutionalist assumptions transitologists thus come to the conclusion that further institutional reforms are needed in order to transform what Guillermo O'Donnell appropriately called "low intensity democracies" into full-fledged liberal democracies. This perspective might be challenged, however, if we have a closer look at the democratic history of European countries. Recent research on European democratization processes (Acemoglu/Robinson 2000; 2006; Bangura 2007; Boix 2003; Huber/Stephens 2001; Rueschemeyer/Huber/Stephens 1992) contributed a vast body of studies and data indicating that early electoral reforms in $19^{\text {th }}$ century Europe did have a significant impact on gradually, but significantly lowering (income) inequality rates. ${ }^{11}$ Despite the fact that European political regimes at that time clearly classified as "deficient" according to current definitions, electoral reforms contributed to the transformation of existing inequality patterns. Consequently, deficient institutions alone do not suffice to explain why such a linkage does not exist in Latin America.

A look at the history of welfare regimes ${ }^{12}$ and social policy reforms further reveals that the missing link between the expansion of

11 Acemoglu/Robinson (2006) analyze the correlation between the expansion of electoral rights and distributional conflicts from a game-theory perspective, see also Boix (2003); for a critical review Ansell/Samuels (2010).

12 In contrast to the term welfare state, welfare regime is a broader concept that includes all institutions and practices to distribute resources. It comprises public policies as well as the informal sector, i.e., care by family members or the social communities. For a definition see Gough/Wood (2006: 1698). 
suffrage and a shift in patterns of inequality cannot be explained by a lack of welfare efforts either. Although commonly considered as one of the central achievements of "Western modernity", quite a number of middle-income countries in this region (Argentina, Brazil, Chile, Cuba and Uruguay) initiated public social policies at the same time or even earlier than their European counterparts, i.e., between the two world wars or shortly after World War II. Social security, public education, and public health systems in some cases date back to the 1920s (Kaufman/Nelson 2004: 249-257; Mesa-Lago 1978; Nelson 2004: 23-28).

On an international scale, Latin American states spend relatively large (relative to BIP per capita) amounts of the public budget on social policies. These comparatively generous social budgets, however, do not have an impact on lowering the blatant disparities of incomes and assets. On the contrary, due to their exclusive focus on a limited number of stake-holders (lawyers, the military, teachers, state employees and workers in key industries) and the fact that formal work contracts serve as gate-keepers for the access to the welfare regimes, social policies and transfers contribute to the reproduction of existing inequality levels (Wehr 2011).

Whether or not the current "left turn" ${ }^{13}$ might lead to a change in existing patterns of inequality is still an open question. Some authors, sharing a rather positive outlook on the current situation, have put forward the hypothesis that the current reform phase might lead to a second incorporation period, one with a similar thrust as the first reforms in the first half of the 20th century in the context of the implementation of state-induced industrialization and import substitution (Luna/Filgueira 2009; Wehr 2011). While leaving out the vast majority of social sectors working within the informal economy, stateinduced import substitution policies did require the incorporation, or rather cooptation of some social groups important to the economic development model: These groups included the rather heterogeneous

13 The following countries have a left or left-of-center government: Argentina (since 2003), Brazil (since 2003), Bolivia (since 2006), Ecuador (since 2007), El Salvador (since 2009), Guatemala (since 2008), Nicaragua (since 2007), Paraguay (since 2008), Uruguay (since 2005) und Venezuela (since 1999). The electoral defeat of the Chilean Concertación (2010) so far has not lead to a reverse trend. See Cameron/Hershberg (2010); Levitsky/Roberts (forthcoming). 
and thin middle classes like the military, lawyers, judges, teachers and other public employees as well as workers in some key industries. Within the current context of post-neoliberal reform agendas, these authors argue, serious attempts are being made by progressive governments to enlarge the rather exclusive circle of original stakeholders. Others, however, are more skeptical, and point to the institutional and structural limits to transformative social reforms (Cameron/Hershberg 2010; Levitsky/Roberts forthcoming; López-Calva/ Lustig 2010). These authors argue, that neither elites nor original stakeholders show a real interest in changing the existing exclusionary matrix. Poverty reduction programs, like the popular conditional cash transfer programs, they argue, constitute a cheap substitute for substantial and costly social reforms.

\section{Structural Social Inequality in the Context of Post-colonial Power Structures and Power Asymmetries}

In a nutshell, the fatal "Latin American equilibrium" (Robinson 2008), i.e., the persistence of above-average inequality rates despite early democratization processes and comparatively well-entrenched political rights and democratic decision-making processes challenges commonly held assumptions about the linkage between democratization processes and patterns of inequality. Even the democratic thrust of the latest wave of democratization starting in the 1980s as well as the restitution and expansion of political rights did not lead to any major changes concerning regional inequality rates so far. Despite some progress in the area of poverty reduction, the overwhelming majority of Latin American citizens still suffer from unequal access to and the distribution of commonly available or desirable goods. Contrary to the concerns articulated by early research on Latin American transition processes, the post-authoritarian regimes proved to be unexpectedly stable. This stability, however, coincided with extremely low levels of democratic quality and the persistence of blatant inequality.

So far, comparative research on Latin America has not answered the central question posed by the problematic coexistence of inequality and democratic decision-making processes in a satisfactory manner. These deficits and blind spots in the comparative research agenda can 
be explained by the fact that different areas of research have been largely locked into their respective silos as well as to a lack of interdisciplinary dialogue between the social and economic sciences and cultural and postcolonial studies. Only recently the tension between democratic decision-making processes and extreme rates of inequality gained more interest inside the Latin American research agenda. Apart from the already mentioned quantitative studies of economic historians, political scientists have made important contributions to the comparative research on long-term patterns of inequality within the region. Methodologically located within historical institutionalism, one strand of research concentrated on the development of critical junctures ${ }^{14}$ and path dependencies in the development of Latin American state structures, political institutions and power asymmetries (Coatsworth 2005; 2008; Ferranti et al. 2004; Engerman/ Sokoloff 2005; 2006; Robinson 2008; 2010). These studies share the assumption that despite a growing democratization pressure, the colonial oligarchical equilibrium based on limited elite coordination via vertical integration managed to reproduce itself and adapt to the major political and institutional reforms throughout the 20th century.

This perspective emphasizes not the persistence of specific institutions, but rather the persistence of an underlying political equilibrium which gives rise to strategies of income redistribution and social control [...] even if existing elites are destroyed, specific political and economic institutions may change, the underlying structures and incentives which gave rise to the previous equilibrium may still exist (Robinson 2008: 183186).

Growing pressure towards more egalitarian forms of social inclusion notwithstanding, underlying power structures and basic mechanisms of exclusion (property rights privileging the rich, constitutional guarantees of privileges; the disregard for meritocratic principles and electoral systems designed according to the needs of the powerful) proved unexpectedly resilient and adaptable to changing social demands despite considerable institutional change. Historical institutionalists are particularly interested in explaining how state structures, political institutions and power constellations change during different phases of (post-)colonial development and how elites manage to perpetuate their

14 For a discussion of the concept focusing on historical causes see Stinchcombe (1968: 101-129). 
privileges despite increasing democratization pressures. This implies analyses of distributional conflicts and of changes to the composition of distributional coalitions over time, including the strategies of disadvantaged social actors and groups fighting for participatory parity (Fraser 2003: 36-37) and a more egalitarian distribution of assets and life chances.

Apart from historical institutionalists, major contributions to the comparative research agenda on democracy and social inequality came from Latin American social scientists themselves. Often personally involved in the political struggle for (re-)democratization, this group of social scientists did not share the neo-institutionalist focus of their European and North American colleagues but instead put their emphasis on actor-centered approaches that focus on citizenship rights and forms of participatory democracy. In the context of ongoing democratization struggles and neoliberal structural reforms, these theorists investigated the scopes of action of different social actors and movements and coalitional strategies which might contribute to the transformation of the political system as such (Avritzer 2009; Cheresky 2006; Dagnino/Olvera/Panfichi 2006; for an overview Wehr 2008).

Despite the vast variety of perspectives characterizing the interdisciplinary research agenda on complex inequalities in Latin America, some common denominators and shared assumptions can be identified:

1) Taking intersectionality seriously: Unlike earlier research on inequalities, which was dominated by Marxist approaches within the social sciences, today's research on complex and multiple inequality regimes (for an explanation of the term see Walby 2009: 58-70) is greatly influenced by insights from gender studies that focus on the interrelations and mutual constitution of multiple sets of asymmetrical social relations: in addition to class, gender and ethnic belonging also play an important role in the analysis of intersectional inequalities.

2) The importance of political factors: Although economic factors like the different modes of integration into global markets and overall economic models and dependencies have an important impact on existing inequality regimes, they are not sufficient to ex- 
plain the blatant social disparities within the region. Current research, thus, places emphasis on the analysis of power structures on the local, national and transnational level contributing to the perpetuation of privileges and access asymmetries.

3) Overcoming methodological nationalism: Whereas much of the traditional research on social inequalities within the region was mainly constrained to the national (or local) level, recent investigations in different academic disciplines have made an explicit attempt to focus on interdependent and relational aspects of complex and multiple inequality regimes beyond the nation-state. Taking insights from the ongoing debates on entangled modernity and history (for conceptional issues see Randeria 1999), recent research has taken a renewed interest into international and transnational exchange processes and inter-regional interdependencies. Although current inequality regimes cannot be directly attributed to colonial legacies, in an indirect manner, legacies in a Braudelian sense, i.e., as longterm historically and structurally anchored prefigurations (Braudel 1972) play an important role in determining current inequality regimes. This has led to the insight that the multiple, not necessarily nested or hierarchically ordered inequality regimes (Walby 2009: 67), cannot be analyzed without taking into consideration inter-, trans- und interregional asymmetrical exchange and communication processes with different spatial and temporal scopes.

The unresolved tension between blatant social inequalities and relatively advanced democratic decision structures does not only present a continuous challenge to political decision-makers within the region but will also occupy the research agendas of social scientists for quite some while. 


\section{References}

Acemoglu, Daron/Robinson, James (2000): "Why Did the West Extend the Franchise? Democracy, Inequality, and Growth in Historical Perspective". In: The Quarterly Journal of Economics, 115, pp. 1167-1199.

Acemoglu, Daron/Robinson, James (eds.) (2006): Economic Origins of Dictatorship and Democracy. Cambridge: Cambridge University Press.

Anderson, Christopher/Beramendi, Pablo (2008): "Income Inequality and Democratic Representation”. In: Anderson, Christopher/Beramendi, Pablo (eds.): Democracy, Inequality, and Representation. New York: Russell Sage Foundation, pp. 3-24.

Annino, Antonio (ed.) (1995): Historia de las elecciones en Iberoamérica, Siglo XIX. México, D.F.: Fondo de Cultura Económica.

Ansell, Ben/Samuels, David (2010): "Inequality and Democratization: A Contractarian Approach”. In: Comparative Political Studies, 43, 12, pp. 1543-1574.

Avritzer, Leonardo (2009): Participatory Institutions in Democratic Brazil. Washington, D.C./Baltimore: Woodrow Wilson Center Press/Johns Hopkins University Press.

Bangura, Yusuf (2007) (ed.): Democracy and Social Policy. Basingstoke: Palgrave Macmillan.

Bangura, Yusuf et al. (2010): Combating Poverty and Inequality. Structural Change, Social Policy and Politics. Genève/New York: UNRISD.

Barros, Ricardo/Carvalho, Mirela de/Franco, Samuel/Mendonça, Rosane (2010): "Markets, the State, and the Dynamics of Inequality in Brazil". In: LópezCalva, Luis/Lustig, Nora (eds.): Declining Inequality in Latin America. A Decade of Progress? New York/Washington, D.C.: United Nations Development Programme/Brookings Institution Press, pp. 134-174.

Baten, Jörg/Mumme, Christina (2010): "Globalization and Educational Inequality during the 18th and 20th Centuries: Latin America in Global Comparison”. In: Revista de Historia Económica, 28, 2, pp. 279-305.

Benton, Allyson Lucinda (2005): "Dissatisfied Democrats or Retrospective Voters? Economic Hardship, Political Institutions, and Voting Behavior in Latin America". In: Comparative Political Studies, 38, 4, pp. 417-442.

Bértola, Luis et al. (2009): "Income Distribution in the Latin American Southern Cone during the First Globalization Boom and Beyond". In: International Journal of Comparative Sociology, 50, 5-6, pp. 452-485.

Boix, Carles (ed.) (2003): Democracy and Redistribution. Cambridge: Cambridge University Press.

Braudel, Fernand (1972): "Geschichte und Sozialwissenschaften - die 'longue durée"”. In: Wehler, Hans Ulrich (ed.): Geschichte und Soziologie. Köln: Kiepenheuer \& Witsch, pp. 189-215.

Bunce, Valerie (2000): “Comparative Democratization. Big and Bounded Generalizations”. In: Comparative Political Studies, 33, 6/7, pp. 703-734.

Cameron, Maxwell/Hershberg, Eric (eds.) (2010): Latin America's Left Turns. Politics, Policies and Trajectories of Change. Boulder: Lynne Rienner. 
Caulfield, Sueann/Chambers, Sarah/Putnam, Lara (eds.) (2005): Honor, Status, and Law in Modern Latin America. Durham/London: Duke University Press.

CEPAL (Comisión Económica para América Latina y el Caribe) (2009): Social Panorama of Latin America. Santiago de Chile.

- (2010): La hora de la igualdad: brechas por cerrar, caminos por abrir. Santiago de Chile.

Cheresky, Isidoro (2006): Ciudadania, sociedad civil y participación política. Buenos Aires: Miño y Dávila.

Coatsworth, John (2005): "Structures, Endowments, and Institutions in the Economic History of Latin America". In: Latin American Research Review, 40, 3, pp. 126144.

- (2008): "Inequality, Institutions and Economic Growth in Latin America". In: Journal of Latin American Studies, 40, pp. 545-569.

Dagnino, Evelina/Olvera, Alberto/Panfichi, Aldo (eds.) (2006): La disputa por la construcción democrática en América Latina. México, D.F.: CIESAS.

Deininger, Klaus/Olinto, Pedro (1999): Asset Distribution, Inequality and Growth (World Bank Policy Research Paper Nr. 2375). Washington, D.C.: World Bank.

Deininger, Klaus/Squire, Lyn (1996): “A New Data Set Measuring Income Inequality". In: World Bank Economic Review, 10, 3, pp. 565-591.

Dobado González, Rafael/García Montero, Héctor (2010): “Colonial Origins of Inequality in Hispanic America? Some Reflections Based on New Empirical Evidence". In: Revista de Historia Económica, 28, 2, pp. 253-277.

Easterly, William (2007): "Inequality does Cause Underdevelopment: Insights from a new Instrument”. In: Journal of Development Economics, 84, 2, pp. 755-776.

ECLAC (Economic Commission for Latin America) (2001): Social Panorama of Latin America 2001. Santiago de Chile.

- (2009): Social Panorama of Latin America 2009. Santiago de Chile.

Engerman, Stanley/Sokoloff, Kenneth (2005): "The Evolution of Suffrage Institutions in the New World". In: Journal of Economic History, 65, 4, pp. 891-921.

- (2006): "The Persistence of Poverty in the Americas: The Role of Institutions". In: Bowles, Samuel/Durlauf, Steven/Hoff, Karla (eds.): Poverty Traps. Princeton/Oxford: Princeton University Press, pp. 43-78.

Ernst, Tanja (2011): “(Post-)koloniale Kulturen der Ungleichheit. Zum Zusammenhang von Ethnizität, Ungleichheit und Demokratie in Lateinamerika". In: Wehr/Burchardt 2011, pp. 45-69.

Escobar, Arturo (1995): Encountering Development: The Making and Unmaking of the Third World. Princeton: Princeton University Press.

Ferranti, David de/Perry, Guillermo/Ferreira, Francisco/Walton, Michael (eds.) (2004): Inequality in Latin America and the Caribbean: Breaking with History? Washington, D.C.: World Bank.

Fornos, Carolina/Power, Timothy/Garand, James (2004): "Explaining Voter Turnout in Latin America, 1980-2000". In: Comparative Political Studies, 37 8, pp. 909940. 
Frankema, Ewout (2009): Has Latin America Always been Unequal? A Comparative Study of Asset and Income Inequality in the Long Twentieth Century. Leiden/ Boston: Brill.

Fraser, Nancy (2003): "Social Justice in the Age of Identity Politics: Redistribution, Recognition, and Participation”. In: Fraser, Nancy/Honneth, Axel: Redistribution or Recognition? A Political-Philosophical Exchange. London: Verso, pp. 7-109.

Gough, Ian/Wood, Geof (2006): "A Comparative Welfare Regime Approach to Global Social Policy”. In: World Politics, 34, 20, pp. 1696-1713.

Hettich, Walter/Winer, Stangley (1999): Democratic Choice and Taxation. A Theoretical and Empirical Analysis. Cambridge: Cambridge University Press.

Hicks, Alexander (ed.) (1999): Social Democracy and Welfare Capitalism: A Century of Income Security Policies. Ithaca: Cornell University Press.

Huber, Evelyne/Stephens, John D. (eds.) (2001): Development and Crisis of the Welfare State. Parties and Policies in Global Markets. Chicago/London: The University of Chicago Press.

Huber, Evelyne/Pribble, Jennifer/Stephens, John D. (2009): "The Politics of Effective and Sustainable Redistribution". In: Estache, Antonio/Leipziger, Danny (eds.): Stuck in the Middle. Is Fiscal Policy Failing the Middle Class? Washington, D.C.: World Bank, pp. 155-188.

Huntington, Samuel (1991): The Third Wave. Democratization in the Late Twentieth Century. Norman: University of Oklahoma Press.

Kahhat, Jaime (2010): "Labor Earnings Inequality: The Demand for and Supply of Skills". In: López-Calva, Luis/Lustig, Nora (eds.): Declining Inequality in Latin America. A Decade of Progress? New York/Washington, D.C.: United Nations Development Programme/Brookings Institution Press, pp. 25-38.

Kaltmeier, Olaf (2011): "Hacienda, Staat und indigene Gemeinschaften. Kolonialität und politisch-kulturelle Grenzverschiebungen von der Unabhängigkeit bis in die Gegenwart". In: Wehr/Burchardt 2011, pp. 29-44.

Kaufman, Robert/Nelson, Joan (eds.) (2004): Crucial Needs, Weak Incentives. Social Sector Reform, Democratization, and Globalization in Latin America. Washington, D.C.: Woodrow Wilson Center Press/The Johns Hopkins University Press.

Korzeniewicz, Roberto Patricio/Moran, Timothy Patrick (2009): Unveiling Inequality. A World-Historical Perspective. New York: Russell Sage Foundation.

Kreckel, Reinhard (ed.) (2004): Politische Soziologie der sozialen Ungleichheit. Frankfurt am Main: Campus.

Kronauer, Martin (2006): "Exklusion" als Kategorie einer kritischen Gesellschaftsanalyse. Vorschläge für eine anstehende Debatte”. In: Bude, Heinz/Willisch, Andreas (eds.): Das Problem der Exklusion. Ausgegrenzte, Entbehrliche, Überflüssige. Hamburg: Hamburger Edition, pp. 27-45.

Kuznets, Simon (1955): "Economic Growth and Income Inequality". In: American Economic Review, 45, 1, pp. 1-28.

Lenski, Gerhard Emmanuel (1966): Power and Privilege: A Theory of Social Stratification. New York: MacGraw-Hill. 
Levitsky, Steven/Roberts, Kenneth M. (eds.) (forthcoming): Latin America's "Left Turn": Democracy, Development, and Political Diversity. Johns Hopkins University Press.

Lindert, Peter H. (2004): Growing Public. Social Spending and Economic Growth since the Eighteenth Century. 2 vols. Cambridge: Cambridge University Press.

Lopez, Humberto/Perry, Guillermo (2008): Inequality in Latin America: Determinants and Consequences (World Bank Policy Research Paper Nr. 4504). Washington, D.C.: World Bank.

López-Calva, Luis/Lustig, Nora (eds.) (2010): Declining Inequality in Latin America. A Decade of Progress? New York/Washington, D.C.: United Nations Development Programme/Brookings Institution Press.

Luna, Juan Pablo/Filgueira, Fernando (2009): "The Left Turns as Multiple Paradigmatic Crises". In: Third World Quarterly, 30, 2, pp. 371-395.

Machinea, José Luis/Hopenhayn, Martín (2005): La esquiva equidad en el desarrollo latinoamericano. Una visión estructural, una aproximación multifacético. Santiago de Chile: CEPAL.

Mainwaring, Scott/Pérez-Liñán, Aníbal (2007): "Why Regions of the World Are Important: Regional Specificities and Region-Wide Diffusion of Democracy". In: Munck, Gerardo (ed.): Regimes and Democracy in Latin America. Theories and Methods. Oxford: Oxford University Press, pp. 199-229.

Meltzer, Allan H./Richard, Scott F. (1981): "A Rational Theory of the Size of Government”. In: Journal of Political Economy, 89, 5, pp. 914-927.

Merkel, Wolfgang $\left({ }^{2} 2010\right)$ : Systemtransformation. Eine Einführung in die Theorie und Empirie der Transformationsforschung. Wiesbaden: VS.

Mesa-Lago, Carmelo (ed.) (1978): Social Security in Latin America: Pressure Groups, Stratification and Inequality. Pittsburgh: University of Pittsburgh Press.

Milanovič, Branko/Lindert, Peter H./Williamson, Jeffrey G. (2008): Ancient Inequality (NBER Working Paper 13550). Cambridge: National Bureau of Economic Research.

Milanovič, Branko/Muñoz de Bustillo, Rafael (2008): "La desigualdad en la distribución de la renta en América Latina: situación, evolución y factores explicativos. Income inequality in Latin America: situation, evolution and explicative factors". In: America Latina Hoy, 48, pp. 15-42.

Nelson, Joan (2004): "The Politics of Health Sector Reform: Cross-National Comparisons”. In: Kaufman, Robert/Nelson, Joan (eds.): Crucial Needs, Weak Incentives. Social Sector Reform, Democratization, and Globalization in Latin Ameri$c a$. Washington, D.C.: Woodrow Wilson Center Press/The Johns Hopkins University Press, pp. 23-64.

Neves, Marcelo (2007): "Die Staaten im Zentrum und die Staaten an der Peripherie: Einige Probleme mit Niklas Luhmanns Auffassung von den Staaten der Weltgesellschaft". In: Neves, Marcelo/Voigt, Rüdiger (eds.): Die Staaten der Weltgesellschaft. Niklas Luhmanns Staatsverständnis. Baden-Baden: Nomos, pp. 181221.

Oettler, Anika (2011): "Gender Divisions: Politische Repräsentation und soziale Ungleichheit”. In: Wehr/Burchardt 2011, pp. 91-106. 
Perry, Guillermo et al. (2006): Poverty Reduction and Growth. From Vicious to Virtuous Circles. Washington, D.C.: World Bank.

Peters, Stefan (2011): "Bildung als Privileg”. In: Wehr/Burchardt 2011, pp. 201-225.

PNUD (Programa para el Desarrollo de las Naciones Unidas) (2004): La democracia en América Latina. Hacia una democracia de ciudadanas y ciudadanos. 3 vols. Buenos Aires: Alfaguara.

Posada-Carbó, Eduardo (1996): Elections before Democracy: The History of Elections in Europe and Latin America. Houndmills/New York: Macmillan/St. Martin's Press.

Prados de la Escosura, Leandro (2007): "Inequality and Poverty in Latin America: A Long-Run Exploration”. In: Hatton, Timothy/O'Rourke, Kevin/Taylor, Alan (eds.): The New Comparative Economic History. Essays in Honor of Jeffrey G. Williamson. Cambridge/London: MIT Press, pp. 291-315.

Randeria, Shalini (1999): "Geteilte Geschichte und verwobene Moderne". In: Rüsen, Jörn et al. (eds.): Zukunftsentwürfe. Ideen für eine Kultur der Veränderung. Frankfurt am Main: Campus, pp. 87-96.

Robinson, James A. (2008): “The Latin American Equilibrium”. In: Fukuyama, Francis (ed.): Falling Behind: Explaining the Development Gap Between the United States. Oxford: Oxford University Press, pp. 161-193.

- (2010): "The Political Economy of Redistributive Policies". In: López-Calva, Luis/Lustig, Nora (eds.): Declining Inequality in Latin America. A Decade of Progress? New York/Washington, D.C.: United Nations Development Programme/Brookings Institution Press, pp. 39-71.

Rueschemeyer, Dietrich/Huber, Evelyne/Stephens, John D. (eds.) (1992): Capitalist Development and Democracy. Chicago: University of Chicago Press.

Sabato, Hilda (ed.) (1999): Ciudadanía politica y formación de las naciones. Perspectivas históricas de América Latina. México, D.F.: FCE.

Schäfer, Armin (2010): "Die Folgen sozialer Ungleichheit für die Demokratie in Westeuropa". In: Zeitschrift für Vergleichende Politikwissenschaft, 4, pp. 121156.

Segura-Ubiergo, Alex (2007): The Political Economy of the Welfare State in Latin America. Cambridge: Cambridge University Press.

Souza, Jessé (2008): Die Naturalisierung der Ungleichheit: ein neues Paradigma zum Verständnis peripherer Gesellschaften. Wiesbaden: VS, Verlag für Sozialwissenschaften.

Thiery, Peter/Merkel, Wolfgang (2010): "Die dritte Demokratisierungswelle in Lateinamerika". In: Merkel, Wolfgang: Systemtransformation. Eine Einführung in die Theorie und Empirie der Transformationsforschung. Wiesbaden: VS, Verlag für Sozialwissenschaften, pp. 205-260.

Tittor, Anne (2011): "Institutionalisierte Ungleichheit im Gesundheitswesen: Zu den politischen Gründen für die Beibehaltung fragmentierter Gesundheitssysteme". In: Wehr/Burchardt 2011, pp. 227-256.

Walby, Sylvia (2009): Globalization and Inequalities. Complexity and Contested Modernities. Los Angeles: Sage. 
Wehr, Ingrid (2008): "Von der low-intensity democracy zur Staatsbürgerschaftsdemokratie? Einige kritische Anmerkungen zur lateinamerikanischen Staatsbürgerschaftsdebatte". In: Lateinamerika Analysen, 20, 2, pp. 94-124.

- (2011): "Wohlfahrtsregime und soziale Ungleichheit in Lateinamerika". In: Wehr/Burchardt 2011, pp. 257-281.

Wehr, Ingrid/Burchardt, Hans-Jürgen (eds.): Soziale Ungleichheiten in Lateinamerika. Neue Perspektiven auf Wirtschaft, Politik und Umwelt. Baden-Baden: Nomos.

Weisbrot, Mark/Sandoval, Luis (2008): “The Distribution of Bolivia's Most Important Natural Resources and the Autonomy Conflicts". In: Center for Economic and Policy Research. Washington, D.C., Issue Brief, July 2008.

Williamson, Jeffrey G. (2010): "Five Centuries of Latin American Inequality". In: Revista de Historia Económica, 28, 2, pp. 227-252.

World Bank (2006): Poverty Reduction and Growth. From Vicious to Virtuous Circles. Washington, D.C. 